\title{
STAKEHOLDERS' PERCEPTIONS OF THE INNOVATION TRENDS IN THE SLOVAK FORESTRY AND FOREST-BASED SECTORS
}

\author{
Erika LOUČANOVÁ ${ }^{1}$, Hubert PALUŠ ${ }^{*}$, Klára BÁLIKOVÁ ${ }^{2}$, \\ Michal DZIAN ${ }^{1}$, Nikola SLAŠŤANOVÁ ${ }^{1}$, Jaroslav ŠÁLKA ${ }^{2}$ \\ ${ }^{1}$ Department of Marketing, Trade and World Forestry, Faculty of Wood Sciences and Technology, \\ Technical University in Zvolen, Zvolen, Slovakia \\ ${ }^{2}$ Department of Economics and Management of Forestry, Faculty of Forestry, \\ Technical University in Zvolen, Zvolen, Slovakia
}

Received 13 October 2019; accepted 05 June 2020

\begin{abstract}
Innovations represent the engine of the business and economic. This is particularly relevant to the traditional sectors such as forestry and forest-based industry that are expected to play an important role in the future steps oriented towards meeting the sustainable development goals. The main aim of this study is to analyse the stakeholders' perceptions of the innovation trends in the forestry and forest-based sectors by using a Q-methodology. This research addressed three groups of respondents in Slovakia, whose task was to subjectively assess innovative trends in the forestry and forest-based sectors. Based on the results it can be concluded that the innovation trend in the forestry and forest-based sectors will be oriented towards the technological progress focused on the increasing efficiency of wood processing and increasing the usability of waste material as well as the trend of increasing development of innovations in the forest recreation services.
\end{abstract}

Keywords: innovation, innovation system, innovation trends, forestry and forest-based sectors, Q-methodology, stakeholders.

JEL Classification: O31, Q57, M29.

\section{Introduction}

The growth of human population and its economic activities are contributing to the utilization of the Earth's natural resources (Kula, 2012). Resources such as water, soil, clean air and ecosystem services are essential for our health and quality of life (de Groot et al., 2002) but current rates of their harvesting and waste generation deplete them faster than they can regenerate (Wackernagel et al., 2002). Forests are strategic source of renewable natural resources and play an important role in the creation and protection of individual components of the natural environment (FAO, 2019). Forestry and forest-based sectors contribute much to the quality of life and sustainable utilization of natural resources (Weiss et al., 2011).

${ }^{\star}$ Corresponding author. E-mail: palus@tuzvo.sk 
The forestry sector represents one of the most important parts of the European bioeconomy and it is expected that the bioeconomy will play an important role in the low carbon economy (Scarlat et al., 2015). The bioeconomy concept comprises the production of renewable biological resources and their conversion together with the waste streams into value added products with the aim to conduct the production and consumption activities in a sustainable way. Some economic sectors, including forestry sector, traditionally use biological resources and processes (Parobek et al., 2016). According to Haarich (2017) there is a wide array of drivers that encourage European countries and regions to invest in the deployment of the bioeconomy. Drivers can be found in the regional resources and assets, not only natural but also related to industrial and scientific knowledge, that can be put into value through innovative techniques and processes. Within the EU Biodiversity Strategy as well as the EU Forestry Strategy the sustainable forestry has been identified as one of the EU's priority. The forestry sector can make use of new opportunities and take a lead in the sustainable development of Europe's bioeconomy. In the transformation to sustainable future forest use the various types of innovations have a prominent role to play (Ludvig et al., 2020).

Therefore, the issue of innovation in this area is becoming more and more important and is devoted an increasing attention (Rametsteiner \& Weiss, 2006). The issue of innovation linked to forest management has been addressed in European countries for more than a decade (Jarský, 2014). Primarily, technological issues such as harvesting, extraction operations and transport have been studied in detail (Nybakk et al., 2015).

Current research has identified innovations as a key engine for economic growth, competitiveness and employment (Rametsteiner \& Weiss, 2006). This is not only relevant for high-tech industries but for all sectors and economies, including forestry (OECD, 2018; Lacko \& Šálka, 2003; Weiss et al., 2011; Rametsteiner \& Weiss, 2006).

Forestry is often considered as a "Low-tech" declining industry (Weiss et al., 2011; Rametsteiner \& Weiss, 2006; Nybakk et al., 2015), which invests relatively little into research, development and innovation. Forestry is a significant source of income for forest owners and for rural people (Sarvašová \& Kovalčík, 2010) and innovations have their particular position and importance in the forestry and forest-based sectors (Rametsteiner \& Weiss, 2006; Lacko \& Šálka, 2003). These findings open opportunities for all kind of innovations in these sectors. In generally, there are two main categories of innovations defined in literature: (i) product and (ii) process innovations (Kubeczko et al., 2006; Lacko \& Šálka, 2003). Product innovations are changes in output of an enterprise or organization that could be material goods and intangible services. Process innovations are changes of technological or organizational processes among the enterprise or organization (Kubeczko et al., 2006).

Implementation of product and process innovations into forestry and forest-based sectors is considered as new opportunity to more efficiently and effectively process the wood fibre resources with new technological equipment or processing methods. Innovation, therefore, potentially increases the value and use of timber (Hansen, 2010). Forestry and forest-based sectors have big potential for adopting new goods and services innovations such as changes in wood products or tourism and recreational products (Weiss et al., 2011). Nowadays, alternative commercial use of forest land is becoming more important, including tourism, recreation and eco-services (Nybakk et al., 2009). This opens space for developing new innovations in 
forestry for people who lives in rural environment (Sarvašová \& Kovalčík, 2010; Weidenfeld, 2018) and for increasing of related outdoor activities and recreational innovations for tourists (Biernacki \& Waldorf, 1981; Sarvašová \& Kovalčík, 2010; Weidenfeld, 2018). Research across the Europe also shows the growing trend in mapping of existing and developing new software solutions in the field of forestry (Orazio et al., 2017). These kinds of product innovations in forestry can also include various software solutions within the framework of forest management (Kumar et al., 2012) as well as the development of applications for the wider public to raise awareness about forest ecosystems (Jepson \& Ladle, 2015). Process innovations in the sector are mainly changes or improvements in wood processing methods (Hovgaard \& Hansen, 2004). This type of innovation is the traditional strength of forest sector companies, driven by high relative raw material input costs and a commodity or production mentality (Hansen et al., 2014). As Hansen et al. (2007) stated there are indications that the forestry and forest-based sector enterprises are aware of the positive relationship between market orientation and innovativeness.

Research of innovations in the Slovak forestry and forest-based sectors has focused on innovative behavior and implementation of innovations within the forest enterprises (Sarvašová \& Kovalčík, 2010), forest contractors, and wood processing enterprises (Loučanová et al., 2017). Research also addressed the barriers to implementation of innovations. Among the main barriers for the development and implementation of innovations in Slovak forestry enterprises are the missing cooperation between the state administration/research institutions and forestry enterprises (Kovalčík et al., 2012; Zaušková et al., 2009), lack of finances, tax load and environmental legislation (Sarvašová \& Kovalčík, 2010). The same barriers are also perceived by the contractors providing services in the forestry (Štěrbová et al., 2016).

The development of innovations is supported and provided by innovation systems, which are made up of a number of different subjects and institutions that include various interconnected stakeholders from public and private sectors (Kubeczko et al., 2006). The stakeholders represent different levels, sectoral, regional and national level. As Edquist and Johnson (1997) point out, innovation systems in relation to innovation fulfil three basic functions: (i) reduce uncertainty by providing information (PI); (ii) manage conflicts and cooperation (MCC); and (iii) provide incentives (I).

Given the current state of the forestry and forest-based sectors in Slovakia, innovation trends in these sectors shall be oriented at the efficient wood processing, technological innovations, new software solutions, innovations services, etc. (Orazio et al., 2017; Sarvašová \& Lásková, 2009; Štěrbová et al., 2016; Štěrbová \& Šálka, 2016, etc.). Živojinović and Wolfslehner (2015) and Nijnik et al. (2018) point out a number of similarities in the perception of future trends in innovation in forestry and forest-based sectors by interested groups in order to more effectively exploit the potential of innovation strategies of these sectors.

An unanswered question remains how innovations in forestry and forest-based sectors are perceived by other stakeholders such as the public community as beneficiary of forest functions and their services (Sarvašová \& Šálka, 2012) and the sector professionals. Based on this review, the main aim of this study is to determine the perceptions of innovation trends in the forestry and forest-based sectors from the point of view of different stakeholder groups by using the Q-method. Stakeholder groups are experts, general public and business 
community. These composition of stakeholders offers an insight into the heterogeneity of attitudes on the issue and allows to point out the differences in perception of innovation trends in these sectors.

The rest of the manuscript is organized as follows. First the material and methods is analysed. This part is oriented towards definition of Q-sample, selection P-sample and Q-sorting. Then, the results of the study are presented, including discourses of experts, general public and business community. In the last part, trends of innovation in the forestry and forestbased sectors are discussed.

\section{Material and methods}

The paper is methodically based on using Q-method, which is widely used in various research fields such as medicine (Cirigliano, 2013; Salloch et al., 2018) policy (Andersen et al., 2018) and many other sectors (Andersen et al., 2018; Dean, 2019). Q-method has also been utilised in forestry and forest-based sectors research (Steelman \& Maguire, 1999; Dasgupta, 2005; Loučanová et al., 2017; Walder \& Kantelhardt, 2018). Živojinović and Wolfslehner (2015) used Q-method interviews to evaluate the perceptions of urban forestry stakeholders towards climate change adaptation in the city of Belgrade in Serbia. The views of respondents were clustered into three distinct perspectives: (a) "management-oriented perspective", (b) "sceptics", and (c) "general-awareness perspective". Nijnik et al. (2018) applied a Q-method to explore experts' attitudes towards forest related decision-making and governance in treeline areas to reveal the existing attitudinal divergences.

This method is an important evaluation tool for the respondents' attitudes about examined issues. As stated by Kállay (2007), Q-methodology is combining qualitative and quantitative approaches to research. As it is primary an exploratory technique it is effective for obtaining data from small samples and allowing comparison of different points of view (Loučanová et al., 2017). It cannot prove hypotheses; however, it is able to generate some consistency to research questions with potentially contested answers (Bucar et al., 2003). A by-person factor analysis is utilised to select groups of participants who are expected to sort a pool of items in comparable ways by asking them to decide what is "meaningful" and hence what does (and what does not) have value and significance from their perspective (Hisrich et al., 1998). Procedures of the application of Q-methodology in this study are summarised as follows.

\subsection{Definition of $Q$ - sample (statements identification)}

The Q-sample was defined as a set of the statements on innovation trends in the forestry and forest-based sectors in Slovakia. These statements were formulated on the basis of a review and analysis of documents presenting the results of innovation-related research and studies (Dobšinská et al., 2010; LIDL, 2018; Marušáková, 2009; Sarvašová, 2008; Sarvašová \& Kovalčík, 2010; Sarvašová et al., 2014; Štěrbová et al., 2016; Štěrbová \& Šálka, 2016) as well as projects such as the IPOLES project dealing with the principles of integration and coordination of innovation, development and environmental policies in forestry in the context of sustainable development (Table 1). These resources present and capture a number of real- 
Table 1. Q - sample formulation

\begin{tabular}{|c|c|c|c|c|}
\hline \multicolumn{2}{|r|}{ Statements } & \multirow{2}{*}{\begin{tabular}{|l}
$\begin{array}{c}\text { Source of the } \\
\text { innovation } \\
\text { trend }\end{array}$ \\
$\begin{array}{l}\text { Sarvašová et al. } \\
\text { (2014), IPOLES }\end{array}$
\end{tabular}} & \multirow{2}{*}{$\begin{array}{c}\text { Type } \\
\text { P-sample* } \\
\text { EX }\end{array}$} & \multirow{2}{*}{$\begin{array}{l}\text { Type inno- } \\
\text { vation/Func- } \\
\text { tions of IS } \\
\\
\text { PS/I }\end{array}$} \\
\hline S1 & $\begin{array}{l}\text { Technological progress will be focused on } \\
\text { increasing the efficiency of wood processing } \\
\text { (e.g., increasing the usability of waste } \\
\text { material). }\end{array}$ & & & \\
\hline S2 & $\begin{array}{l}\text { New software solutions will be developed } \\
\text { within the forestry and forest-based sectors } \\
\text { (e.g., improvement of game management } \\
\text { using the satellite technology; creation } \\
\text { of maps with hiking trails; creation of } \\
\text { educational apps). }\end{array}$ & $\begin{array}{l}\text { Orazio et al. } \\
\text { (2017); Jepson } \\
\text { and Ladle } \\
(2015)\end{array}$ & $\mathrm{BC}$ & PT/PI, I \\
\hline S3 & $\begin{array}{l}\text { State forest administration and educational } \\
\text { institutions will organize more events for } \\
\text { general public with the aim of raising the } \\
\text { knowledge about importance of forest } \\
\text { ecosystems. }\end{array}$ & $\begin{array}{l}\text { Marušáková } \\
\text { (2009), IPOLES }\end{array}$ & EX & PS/PI \\
\hline S4 & $\begin{array}{l}\text { In addition to rural development, policy } \\
\text { programs will also focus on forestry as } \\
\text { segregated sector, despite of its importance } \\
\text { to rural policy. }\end{array}$ & $\begin{array}{l}\text { Dobšinská et al. } \\
\text { (2010), IPOLES }\end{array}$ & GP & PS/PI, I \\
\hline S5 & $\begin{array}{l}\text { The highest interest in innovations in } \\
\text { forestry and forest-based sector enterprises } \\
\text { will be in the field of forest technology. }\end{array}$ & $\begin{array}{l}\text { Sarvašová et al. } \\
\text { (2014), IPOLES }\end{array}$ & $\mathrm{BC}$ & $\mathrm{PT}$ \\
\hline S6 & $\begin{array}{l}\text { Development and implementation } \\
\text { of innovations and monitoring of } \\
\text { innovation opportunities will increase the } \\
\text { competitiveness of forest enterprises. }\end{array}$ & $\begin{array}{l}\text { Sarvašová et al. } \\
\text { (2014); Štěrbová } \\
\text { et al. (2016), } \\
\text { IPOLES }\end{array}$ & GP & PS/MCC \\
\hline S7 & $\begin{array}{l}\text { Research and educational institutions will } \\
\text { regularly organize seminars for forestry and } \\
\text { forest-based sector enterprises with the aim } \\
\text { to introduce the possibilities of financial } \\
\text { support, development and implementation of } \\
\text { innovations. }\end{array}$ & $\begin{array}{l}\text { Štěrbová and } \\
\text { Śálka (2016), } \\
\text { IPOLES }\end{array}$ & GP & PS/PI \\
\hline S8 & $\begin{array}{l}\text { The innovations in forest recreation } \\
\text { services will increase (e.g., building of new } \\
\text { educational walkways and bicycle lanes; } \\
\text { forest pedagogy actions). }\end{array}$ & $\begin{array}{l}\text { Sarvašová and } \\
\text { Kovalč́k (2010); } \\
\text { Sarvašová } \\
(2008), \text { IPOLES }\end{array}$ & $\mathrm{BC}$ & PT \\
\hline S9 & $\begin{array}{l}\text { Increasing of voluntary activities for the } \\
\text { protection and afforestation of the forest } \\
\text { ecosystems in the context of Corporate } \\
\text { social responsibility (CSR) (e.g., part of the } \\
\text { enterprise's profit goes to reforestation) }\end{array}$ & LIDL (2018) & EX & PS/MCC \\
\hline
\end{tabular}

Note: ${ }^{\star}$ EX - experts from the field, BC - business community, GP - general public, PT - product innovation, PS - process innovation; ${ }^{* *}$ Function related on innovation in statement/if applicable, I - provide incentives, PI - reduce uncertainty by providing information, MCC - manage conflicts and cooperation. 
world examples of discourses around the innovation trends in the forestry and forest-based sector in Slovakia. Except of this extensive review of the academic literature there were pilot interviews carried out with people within the sectors. In this way, 165 statements items were structured. The statements were refined into a final Q-set of 9 items by removing repetition, duplication and ambiguity, to ensure clarity of statements (Perz et al., 2013), so they covered all the trends of innovation in forestry and forest-based sectors in Slovakia within the relevant conceptual space and they were not biased towards a particular viewpoint. Finally, the statements were edited and reworded to ensure that each expressed a distinct perspective on trends of innovation. These statements were chosen on the basis of the theory of innovation system (Functions of innovation system: I - provide incentives, PI - reduce uncertainty by providing information, MCC - manage conflicts and cooperation) and theory of innovations classification into product (PT) and process innovations (PS).

Selected statements reflected the opinions of the 3 groups of respondents representing sectoral innovation system: (i) experts from the forestry and forest-based sectors (EX), (ii) business community (BC) and (iii) general public (GP).

Based on the comprehensive analysis of statements each statement was assigned to one the proposed groups. Statements S1, S3 and S9 reflected the views of the experts from the field. These statements suppose that trends in the innovations in forestry and forest-based sectors will be oriented towards process innovations (PS) linked to the idea of circular economy (e.g. more efficient use of wooden waste) and to the raising awareness about the forest ecosystems and their importance for the people. Such formulation of the statements that are focused on the development of process innovations is geared towards the transfer of innovations into practice with respect to the trends in the given issue. Although a lack of financial resources does not allow investing into new technologies in forestry (Jarský, 2014), companies are searching opportunities for implementation of innovation in the context of corporate social responsibility (CSR) (Dobšinská et al., 2010).

Statements S4, S6 and S7 reflect the opinions of the general public. Similarly, as in the case of the group of experts, these statements are oriented on process innovations (PS) with the emphasis on the role of the information for the development and support of the innovativeness in forestry and forest-based sectors. General public perceive the trends in innovations in forestry and forest-based sectors mediated through the different types of media. As they do not understand the current situation in the sector in details their views are rather oriented towards the future development of the role of innovation and development of related policies. Information is an opportunity to spread innovation in forestry (Štěrbová et al., 2016). However, the existing knowledge base for innovation in Slovakia does not represent effective information paths for innovation development and it does not provide appropriate advice and guidance for the innovation development.

Statements S2, S5 and S8, in contrast to the others, represent product innovations (PT) and the opinions of respondents representing the business community. The business community has a direct impact on the changes in the field of products innovations (Kubeczko et al., 2006), adapting to their needs in the marketplace, focusing on sustained management based on the principles of CSR. As already mentioned above the technology in forestry sector is outdated in Slovakia. Selected technological issues such as harvesting, extraction opera- 
tions and transport are studied in detail by Nybakk et al. (2015). As tourisms in Slovakia is underdeveloped, providing recreational services in the forests is a great opportunity for entrepreneurs to implement a wide scope of innovation related to the forest recreation in synergy with the development of software solutions (Weidenfeld, 2018).

\subsection{Selection $\mathbf{P}$ - sample (sample of respondents)}

The use of Q-methodology enables respondents to express their viewpoints with minimal researcher interference. In the application of Q-methodology, the domain is subjectivity and research is performed on small samples (Loučanová et al., 2017). Q-methodology is less concerned with the ability to generalize the findings from the analysis, and it uses smaller, well-selected samples to analyse variability within cases. It also does not yield statistically generalizable results. Instead, the results produce an in-depth portrait of the typologies of perspectives that prevail in a given situation (Steelman \& Maguire, 1999). Low response rates do not bias Q-methodology because the primary purpose is to identify a typology, not to test the typology's proportional distribution within the larger population (Valenta \& Wigger, 1997). As Bošanský and Fulková (2009) point out, the Q-method does not require the minimum number of respondents, their number is not decisive and can range from 1-500.

The experts from the field (scientific community and education in the field of forestry and wood sciences), business representatives (forestry and forest-based industry professionals) as well as representatives of general public were identified and contacted for the purposes of the determination of P-sample of respondents. For this study the final sample size (P-sample of respondents) was set to 75 respondents, out of which 14 were representatives of experts from the field of forestry and forest-based industry, 14 represented actors from the business community, and 47 respondents represented the general public. A snowball sampling method was used for the selection of respondents from (i) the scientific community and education (experts) and (ii) from the industry. First of all, known scientific community representatives were contacted. They provided contacts to other experts. According to Biernacki and Waldorf (1981) snowball sampling is a qualitative method that has been widely used in sociological research. This method helps researcher set up a study sample through referrals made within respondents who share or know of others who possess some characteristics that are of research interest. The general public respondents were chosen by simple random selection using the publicly available list of inhabitants in Slovakia (Zoznam.sk, 2019).

\subsection{Q-Sorting (research implementation to determined sample of respondents)}

For the purposes of this study there was a structured interview used to address 75 respondents. The interview was provided in the Slovak language. The interview included the selection of the Q-sample evaluation method, the determination of the positive-negative value line and the determination of the "forced" distribution (Schmolck, 2017; Watts \& Stenner, 2005) which gives the number of statements that can be assigned to each position as shown in Figure 1. Respondents were presented with the statements presenting innovative trends in the forestry and forest-based sectors. Subsequently, based on their perception of these statements they were asked to determine the positive-negative value line and use the "forced" 
distribution pattern (Q-grid). In particular, the following question was posed: How will the innovation trends in the forestry and forest-based sectors develop in Slovakia?

\begin{tabular}{|l|c|c|c|c|}
\hline & & & & \\
\cline { 2 - 5 } & & & & \\
\cline { 2 - 5 } & & & \\
\hline Most disagree & & & & +1 \\
\hline
\end{tabular}

Figure 1. Shape of the used Q-grid (Loučanová et al., 2017)

\subsection{Analysis and interpretation}

Collected data were analysed by using the PQMethod software (Loučanová et al., 2017; Schmolck, 2017; Watts \& Stenner, 2005). PQMethod is a statistical program tailored to the requirements of Q-studies. Specifically, it allows to enter data (Q-Sorts) the way they are collected. It computes intercorrelations among Q-Sorts, which are then factor-analysed with the Centroid or, alternatively, PCA method. Resulting factors shall be rotated analytically (Varimax) (Loučanová et al., 2017). The interpretation of results was based on the calculated indicators. In total, there were 9 number of sorted statements while the Q-sort column values ranked from -2 to +2 . These statements were assigned to individual scale values that followed the following pattern: 122321 . All calculated intercorrelations among Q-sorts were factor-analysed with the centroid method and resulting factors were rotated analytically. Finally, z-scores and factor scores were calculated for the three identified relevant factors and Q-sort values obtained for statements sorted from most disagreement to most agreement (Loučanová et al., 2017; Schmolck, 2017; Watts \& Stenner, 2005). Factor interpretation was based upon a thematic reading of statements and their position in the context of all other statements in the final factor arrays. Differences between factors were articulated by examining distinguishing statements (statements with statistically different factor scores across factor arrays, for $\alpha=0.05$ ). Consensus statements (statements that do not distinguish between any of the significant factors) were also examined to identify similarities between the factors.

\section{Results}

Acquired data were analysed using the PQMethod software. Results in the form of factor scores are shown in Table 2. In order to facilitate the interpretation of results an abbreviated form of statements was developed. A "factor score" of each statement represents the Z-score (normalized weighted average statement score) of respondents defining the given factor (Loučanová et al., 2017; Schmolck, 2017). Based on these values there were three Q-grids reflecting the differences in respondent statements developed.

In order to define mutual relations distribution of factor scores within each factor were compared with the types of statements. At the poles of the distribution of factor A there are several statements related to the attitudes of expert from the field (S1 ranked 2, S3 ranked 1), for factor B statements related to the attitudes of general public (S4 ranked 2) and for factor 
C statements related to the attitudes of business community (S8 ranked 2). Q-grids for all three factors (factor scores) are illustrated in Figure 2.

Table 2. Factor scores

\begin{tabular}{|c|l|c|c|c|}
\hline \multirow{2}{*}{ Statements (abbreviated form) } & \multicolumn{3}{c|}{ Factor scores } \\
\cline { 3 - 5 } \multicolumn{2}{|c|}{} & A & B & C \\
\hline S1 & Efficient wood processing & +2 & +1 & -1 \\
\hline S2 & New software & -1 & -2 & 0 \\
\hline S3 & Events for general public & +1 & 0 & -2 \\
\hline S4 & Focused policy programs & -2 & +2 & -1 \\
\hline S5 & Technological innovations & 0 & 0 & 0 \\
\hline S6 & Innovations as a source of competitiveness & 0 & -1 & 0 \\
\hline S7 & Information and educational seminars. & -1 & 0 & +1 \\
\hline S8 & Innovations in forest recreation & 0 & +1 & +2 \\
\hline S9 & Socially responsible innovations & +1 & -1 & +1 \\
\hline
\end{tabular}

\begin{tabular}{|c|c|c|c|c|}
\hline \multirow[t]{3}{*}{4} & 2 & 5 & 3 & 1 \\
\hline & 7 & 6 & 9 & \\
\hline & & 8 & & \\
\hline-2 & -1 & 0 & +1 & +2 \\
\hline
\end{tabular}

Factor A

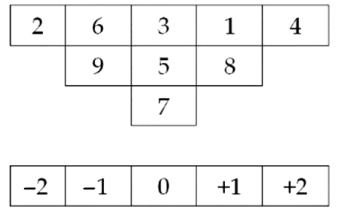

Factor B

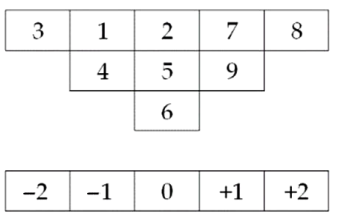

Factor C

Figure 2. Q-grids

Table 3 presents the number of members of each stakeholder group who loaded significantly for each factor. The study revealed three discourses: Trends of the experts from the field, Trends of general public and Trends of business community.

Table 3. Stakeholders' loading on each factor

\begin{tabular}{|l|c|c|c|c|c|c|}
\hline \multicolumn{1}{|c|}{ Stakeholder groups } & \multicolumn{2}{c|}{ Factor A } & \multicolumn{2}{c|}{ Factor B } & \multicolumn{2}{c|}{ Factor C } \\
\hline Experts from the field & 3 & -1 & \multicolumn{2}{c|}{2} & \multicolumn{2}{c|}{2} \\
\hline General public & 4 & -5 & 10 & -1 & 3 & -1 \\
\hline Business community & \multicolumn{2}{|c|}{0} & 4 & -1 & \multicolumn{2}{|c|}{5} \\
\hline
\end{tabular}

\subsection{Discourse A: Trends perceived by the experts from the field}

This discourse agrees to S1 and disagrees to S4 as "strong" statements. Experts from the forestry and forest-based sectors are convinced, that innovations in the field of forestry and forest-based sectors will focus mainly on process innovation - efficiency of wood processing $(\mathrm{S} 1+2 / 1.54)$, socially responsible innovations $(\mathrm{S} 9+1 / 1.24)$ and organisation of events for general public ( 3 ranked $+1 / 0.58)$. On the other hand, this group assumes that the separation of forest policy programs from Rural Development Program will be very improbable 
(S4 -2/-1.19). Also, they do not think that there will be new software solutions developed $(\mathrm{S} 2-1 /-1.22)$ and that the state institutions will regularly organize information and educational seminars $(\mathrm{S} 7-1 /-0.87)$. Respondents of this group were neutral regarding the technological innovation (S5 0/-0.28), role of innovation as a source of competitiveness (S6 0/0.18), and innovations in forest recreation (S8 0/0.02).

\subsection{Discourse B: Trends perceived by general public}

This discourse agrees to S4 and disagrees to S2 as "strong" statements. Trends perceived most positively by the general public relate to the focused policy programmes ( $\mathrm{S} 4$ ranked $+2 / 1.41$ ), efficiency of wood processing $(\mathrm{S} 1+1 / 1.19)$, and innovations in forest recreation services (e.g. building of new educational walkways and bicycle lanes; forest pedagogy events) $(\mathrm{S} 8+1 / 0.94)$. On the contrary, respondents in this group perceive as unlikely trends those oriented towards the development of new software solutions (S2 -2/-1.17), development and implementation of innovations that would increase the competitiveness of forestry and forest-based sector enterprises (S6 -1/-0.94), and socially responsible innovations (S9 -1/-1.11). The following statements are perceived neutrally: events for general public (S3 0/-0.27), technological innovations (S5 0/0.27), and information and educational seminars (S7 ranked 0/-0.31).

\subsection{Discourse C: Trends perceived by business community}

This discourse agrees to S8 and disagrees to S3 as "strong" statements. The actors from the business community positively perceive the trends in the innovations in forest recreation services $(S 8+2 / 1.71)$, information and educational seminars $(S 7+1 / 0.86)$, and socially responsible innovations $(S 9+1 / 1.02)$. On the contrary, as the least likely to happen are the trends related to the organisation of events for general public (S3 -2/-1.03), technological innovations in wood processing ( $\mathrm{S} 1-1 /-0.87)$, and focused policy programmes ( $44-1 /-0.87)$. The respondents from business community perceive neutrally the following statements: new software solutions (S2 0/-0.11), technological innovations (S5 0/-0.64), and the development and implementation of innovations and monitoring of innovation opportunities that would increase the competitiveness of forest enterprises (S6 0/0.10).

\section{Discussion}

The main aim of this study is to analyse stakeholders' perceptions of innovation trends in forestry and forest-based sectors using Q-methodology in Slovakia. It aims to point out the differences in the perception of innovation trends in these sectors by interested groups - experts, business community and general public, and indicate the limitations of enterprises to implement innovations defined by the respective stakeholders. Based on the presented results it can be expected that the trends of innovation in the forestry and forest-based sectors will be focused on the increase in efficiency of wood processing and usability of waste material (S1), development of innovations in forest recreation services (S8) and socially responsible innovations (S9). Each of these trends was perceived at least by two examined groups ( $\mathrm{S} 1$ by $\mathrm{A}+2 / 1.54$ and $\mathrm{B}+1 / 1.19$; 88 by $\mathrm{B}+1 / 0.94$ and $\mathrm{C}+2 / 1.71$; S9 by $\mathrm{A}+1 / 1.24$ and $\mathrm{C}+1 / 1.02$ ). 
Increasing the efficiency of wood processing and usability of waste material is a global trend (Paluš, 2015; Paluš et al., 2014; Štěrbová et al., 2016) and within this research it is emphasised by the trends perceived by the experts from the field $(\mathrm{S} 1+2 / 1.54)$ as well as those of general public $(S 1+1 / 1.19)$. Wear of machinery and technical equipment in the given sector in Slovakia is generally well known (Loučanová et al., 2017; Štěrbová et al., 2016) and therefore the need for innovation is not only recognized by the experts from the field but also by the general public. The business community also recognizes this issue, however they do not perceive the innovation trend in this area to be significant $(\mathrm{S} 1-1 /-0.87)$ as they are aware of the lack of funding to introduce radical (significant) technological innovations. This is because the innovation system fails in providing the information about the financing opportunities and financial incentives in the field of innovation (Šálka et al., 2006). Similar conclusions have been drawn in the study by Loučanová et al. (2017) showing that innovation activities will be related to the innovation of existing technologies in order to meet the requirements of existing standards. This difference in the future orientation of innovation is mainly due to the lack of financial resources to support innovation in small businesses.

Companies in this sector are willing to invest in innovation only under certain conditions, related to risk reduction. For example, forest contracting companies have a weak negotiating position with limited scope to meet the conditions that would effectively protect them from the possible opportunistic behaviour of forest owners. Huge innovations are therefore not common in this sector. Usually, they are represented only by small modifications of the technologies used for the specific requirements of each customer or due to working conditions (Paluš et al., 2011). It seems therefore obvious that the actors representing business community perceive future innovation trends in forest recreational services rather than in process innovations, as process innovations are focused more on "mature" sectors (in particular, opportunities are pursued by introducing innovations related to reducing production cost) (Kubeczko et al., 2006). The actors representing the business community thus perceive positively trends that are linked to meeting the needs of customers (demands from the general public) in an efficient and cost-effective way in order to meet the organisation's objectives (Kotler, 1995) $(S 8+2 / 1.71)$. A trend in increasing innovation in forest recreational services was also expected by the actors representing the general public $(S 8+1 / 0.94)$. Other related studies have also drawn similar conclusions about increasing development of innovations in forest recreation (Loučanová et al., 2014; Parobek et al., 2014). Furthermore, the role of consumers must be given a more prominent place, as co-creators of the value added to the products. Consumer or user-oriented innovation approaches seem promising as innovation strategies (Živojinović et al., 2020). The forestry and forest-based sector enterprises are focused on the product innovations (Hansen et al., 2007) and not on the process ones, which are perceived as more likely by the experts (S8 0/0.02). Based on the presented results, it can be concluded that innovation system is failing in its two basic functions - (i) a lack of information and (ii) lack of incentives.

The innovation trend oriented towards the long-term competitive advantages is involved in the statement S9 related to support and promotion of the context of corporate social responsibility. This statement was similarly perceived by the respondents of business community $(\mathrm{S} 9+1 / 1.24)$ as well as the experts from the field $(\mathrm{S} 9+1 / 1.02 \mathrm{C})$. This innovative trend 
extends the basic magic triangle of neoclassical financial theory by a fourth dimension of social responsibility (Paluš et al., 2011), which in terms of investment decision-making on innovation represents an investment discipline based on environmental, social and ethical criteria generating long-term competitive returns and positive social impact (State Enterprise Forests of the Slovak Republic, 2017). This is perceived as an effective marketing tool in order to distinguish a company from its competitors and it is also often used by the companies in the sector (State Enterprise Forests of the Slovak Republic, 2017). However, as claimed by Pätäri et al. (2017), CSR should be viewed as the complex and context-dependent nature of sustainable forest use in a future bioeconomy that cannot be managed at the corporate level, but is dependent on perceptions, values, and levels of industry knowledge among stakeholders.

Forest related decision-making requires a high level of stakeholder competence and capacity building. An improved knowledge of experts' attitudes, together with an emphasis on increased participation in decision-making, could be of help to policy and practice communities in triggering innovative changes locally. Hence, it can be concluded that there is a missing management of conflicts and cooperation (Štěrbová et al., 2016).

Based on the findings it is also possible to state that communication and cooperation between the experts from the field and actors from the business community is deficient, which is outlined in other studies (Sarvašová \& Kovalčík, 2010) as well and, again, to point out a lack of information and cooperation and conflicts management. It also follows from the results that actors from the group of experts from the field perceive the future innovation trends especially in technological progress focused on the increase in efficiency of wood processing and usability of waste material, which is in line with a global trend (Paluš, 2015; Paluš et al., 2014; Štěrbová et al., 2016) and, as well as the fact that the forest and forest technology machinery and equipment are obsolete in Slovakia (Paluš et al., 2015). However, actors representing the business community perceive this trend as improbable as they are aware of the lack of financing innovations in technological equipment (Štěrbová et al., 2016). The National program for the Utilization of Wood Potential in the Slovak Republic (Ministry of Agriculture of the SR, 2018) calls for the financial incentives for innovation support, especially in small and medium companies. Actors representing the category of business community also coincide with the negative trends in innovations in the field under research, such as the fact, that the policy programs will not deal with the development of forestry as a separate component. According to Šálka (2004) the exclusive programs of innovation policy only for forestry at the level of the Slovak Republic and the European Union are very unrealistic. One of the reasons is an increasing trend in policy coherency and raising intersectoral integration (Dobšinská et al., 2010). In this case all the above-mentioned innovation system functions are absent.

Despite the fact, that the general public perceives the situation in the forestry and forestbased sectors differently compared to the experts from the field and actors from business community, it can be concluded that the business community representatives are aware of the needs of the general public (Loučanová et al., 2014; Parobek et al., 2014) and therefore consider the trend of increasing development of innovations in forest recreation services as probable. On the contrary, general public may not recognize the challenges of forest and forest-based enterprises in perceived trends and, therefore, does not perceive some aspects 
as negative as the enterprises and experts in the field. It follows that there is a fragmentation of opinions in the given issue that is caused by different attitudes to the given issue, different ways of its perception and often a lack of information about the issue (Fazekašová, 2006). It is therefore recommended to strengthen the cooperation by involving all stakeholders. Several studies (Hansen et al., 2014; Loučanová et al., 2017; Rametsteiner \& Weiss, 2006; Štěrbová et al., 2016) also confirm that the best way how to eliminate the identified nonconformities in innovation trends in the forestry and forestry-based sectors is to get joined mutually into informal units assisting each other but, on the other hand also to compete at the market.

Big differences in the perception of innovation trends in the forestry and forest-based sectors among stakeholder groups are due to the weak innovation system. In this context, it can be recommended to reinforce the existing cooperation through model innovation system focusing on its functions: reduction of uncertainties by providing information, management of conflicts and cooperation, and the provision of financial and non-financial incentives. This may stimulate innovation in the forestry and forest-based sectors.

The different stakeholder groups perceive the innovation trends in the forestry and forest-based sectors quite differently. The perception of innovation trends pointed out several weaknesses related to awareness, innovation system in Slovakia, intersectoral integration, lack of financial resources as well as some needs such as the support to the development of innovation system. The strength of the most perceived trends of innovations among all stakeholders is the need for technological progress focused on the increase in efficiency of wood processing and usability of waste material, provision of forest recreation services.

\section{Conclusions}

The main aim of this study was to analyse the stakeholders' perceptions of the innovation trends in the forestry and forest-based sectors by using a Q-methodology in Slovakia. The identified differences in opinions between surveyed groups of respondents follow from their different attitudes to this issue, different ways of its perception and often from the lack of information on the issue. It is therefore recommended to improve mutual cooperation with the involvement of all stakeholders.

Based on the above findings, in particular, the following conclusions can be drawn:

- the most perceived trends of innovations in the forestry and forest-based sectors in Slovakia are related to:

- the technological progress focused on increasing the efficiency of wood processing and increasing the usability of waste material,

- the provision of forest recreation services, and

- voluntary activities for the protection and afforestation of the forest ecosystems in the context of corporate social responsibility;

- experts and the public perceive innovation in the forestry and forest-based sectors in Slovakia through the implementation of process innovation;

- business community focuses on innovations meeting the needs of customers (product innovation) in an efficient and cost-effective way as they are aware of the lack of funding to introduce radical technological innovations (process innovation); 
- differences in perception of the future orientation of innovation trends is mainly due to the lack of financial resources to support innovation, a lack of information about the issue and inefficient innovation system in Slovakia;

- innovation system is deficient and next goals should be focused on increasing the efficiency of its functions;

- in this context, it can be recommended to reinforce the existing cooperation through the reduction of uncertainties by providing information, management of conflicts, and the provision of financial and non-financial incentives.

The limits of the study relate to the process of selection of Q-sample as they generalise the potential innovation trends in the forestry and forest-based sectors defined by the experts. Nowadays, innovation represent the engine of the business that are expected to play an important role in the future steps oriented towards meeting the sustainable development goals and this represents additional research potential.

\section{Acknowledgements}

The authors are grateful for the support of the Scientific Grant Agency of the Ministry of Education, Science, Research, and Sport of the Slovak Republic, Grant No. 1/0674/19, "Proposal of a model for the eco-innovation integration into the innovation process of companies in Slovakia in order to increase their performance", Grant No. 1/0666/19 Determination of the development of a wood-based bioeconomy, Grant No. 009TU Z-4/2019 "Modernization of teaching environmental economics at technical universities in the Slovak Republic", and APVV-17-0232 Testing novel policies and business models for provision of selected forest ecosystem services.

\section{Funding}

This work was supported by the $<$ Scientific Grant Agency of the Ministry of Education, Science, Research, and Sport of the Slovak Republic > under Grant [number 1/0674/19]; <Scientific Grant Agency of the Ministry of Education, Science, Research, and Sport of the Slovak Republic> under Grant [number 1/0666/19]; <Cultural and Educational Grant Agency of the Ministry of Education, Science, Research, and Sport of the Slovak Republic $>$ under Grant [number 009TU Z-4/2019]; and <Slovak Research and Development Agency of the Ministry of Education, Science, Research, and Sport of the Slovak Republic > under Grant [number APVV-17-0232].

\section{Author contributions}

Klára Báliková prepared the literature review, data collection and methodology. Erika Loučanová, Hubert Paluš, Michal Dzian, Nikola Slaštanová and Jaroslav Šálka elaborated chapters Materials and Methods, Results, Discussion and Conclusions. 


\section{Disclosure statement}

We declare that we do not have any competing financial, professional, or personal interests from other parties.

\section{References}

Andersen, R. H., Schulze, J. L., \& Seppel, K. (2018). Pinning down democracy: A Q-method study of lived democracy. Polity, 50(1), 4-42. https://doi.org/10.1086/695417

Biernacki, P., \& Waldorf, D. (1981). Snowball sampling: Problems and techniques of chain referral sampling. Sociological Methods \& Research, 10(2), 141-163. https://doi.org/10.1177/004912418101000205

Bošanský, B., \& Fulková, E. (2009). Q-metóda: Čo to je a ako na to? http://www.paidagogos.net/issues/2009/1/1/article.php

Bucar, B., Glas, M., \& Hisrich, R. D. (2003). Ethics and entrepreneurs: An international comparative study. Journal of Business Venturing, 18(2), 261-281. https://doi.org/10.1016/S0883-9026(01)00083-0

Cirigliano, M. M. (2013). Musical mnemonics in health science: A first look. Medical Teacher, 35(3), e1020-e1026. https://doi.org/10.3109/0142159X.2012.733042

Dasgupta, P. (2005). Q-Methodology for mapping stakeholder perceptions in participatory forest management (Annex B3 of the Final Technical Report of project R8280). Delhi.

de Groot, R. S., Wilson, M. A., \& Boumans, R. M. (2002). A typology for the classification, description and valuation of ecosystem functions, goods and services. Ecological Economics, 41(3), 393-408. https://doi.org/10.1016/S0921-8009(02)00089-7

Dean, R. (2019). Control or influence? Conflict or solidarity? Understanding diversity in preferences for public participation in social policy decision making. Social Policy \& Administration, 53(1), 170-187. https://doi.org/10.1111/spol.12445

Dobšinská, Z., Sarvašová, Z., \& Šálka, J. (2010). Changes of innovation behaviour in Slovakian forestry. The Annals of the "Stefan cel Mare" University of Suceava. Fascicle of the Faculty of Economics and Public Administration, 10(2(12)), 71-80.

Edquist, C., \& Johnson, B. (1997). Institutions and organizations in systems of innovation. In C. Edquist (Ed.), Systems of innovation: Technologies, organizations and institutions. Pinter Publishers/Casell Academic.

FAO. (2019). The state of the world's forests 2018 - Forest pathways to sustainable development. Rome.

Fazekašová, M. (2006). Podniková kultúra vo vybraných podnikatelských subjektoch PPoK (Autoreferát dizertačnej práce). Nitra.

Haarich, S. (2017). Bioeconomy development in EU regions: Mapping of EU Member States' / regions' research and innovation plans \& strategies for smart specialisation (RIS3) on Bioeconomy (Final Report). European Commission, Brussels.

Hansen, E., Juslin, H., \& Knowles, C. (2007). Innovativeness in the global forest products industry: Exploring new insights. Canadian Journal of Forest Research, 37(8), 1324-1335. https://doi.org/10.1139/X06-323

Hansen, E. N. (2010). The role of innovation in the forest products industry. Journal of Forestry, 108, $348-353$.

Hansen, E., Nybakk, E., \& Panwar, R. (2014). Innovation insights from North American forest sector research: A literature review. Forests, 5(6), 1341-1355. https://doi.org/10.3390/f5061341

Hisrich, R. D., Peters, M. P., \& Stepherd, D. (1998). Entrepreneurship. McGraw-Hill. 
Hovgaard, A., \& Hansen, E. (2004). Innovativeness in the forest products industry. Forest Products Journal, 54(1), 26-33.

Jarský, V. (2014). Inovace v lesním hospodářství - systémový pohled. Powerprint (in Czech).

Jepson, P., \& Ladle, R. J. (2015). Nature apps: Waiting for the revolution. Ambio, 44, 827-832. https://doi.org/10.1007/s13280-015-0712-2

Kállay, É. (2007). Q methodology: The investigation of meaning systems in different life-conditions through proverbs. Cogniţie, Creier, Comportament, 11(2), 353-369.

Kotler, P. (1995). Marketing - Management. Victoria Publishing (in Slovak).

Kovalčík, M., Sarvašová, Z., Schwarz, M., Moravčík, M., Oravec, M., Lásková, J., \& Tutka, J. (2012). Financial and socio-economic impacts of nature conservation on forestry in Slovakia. Journal of Forest Science, 58, 425-435. https://doi.org/10.17221/14/2012-JFS

Kubeczko, K., Rametsteiner, E., \& Weiss, G. (2006). The role of sectoral and regional innovation systems in supporting innovations in forestry. Forest Policy and Economics, 8(7), 704-715. https://doi.org/10.1016/j.forpol.2005.06.011

Kula, E. (2012). Economics of natural resources, the environment and policies. Springer Science \& Business Media.

Kumar, N., Belhumeur, P. N., Biswas, A., Jacobs, D. W., Kress, W. J., Lopez, I. C., \& Soares, J. V. (2012). Leafsnap: A computer vision system for automatic plant species identification. In Lecture Notes in Computer Science: Vol. 7573. Computer Vision - ECCV 2012 (pp. 502-516). Springer. https://doi.org/10.1007/978-3-642-33709-3_36

Lacko, M., \& Šálka, J. (2003). Podnikatelské a inovačné správanie lesných podnikov v SR. In Financovanie 2003 (pp. 67-75). Technical University in Zvolen (in Slovak).

LIDL. (2018). Water for Trees in High Tatras.

Loučanová, E., Paluš, H., \& Dzian, M. (2017). A course of innovations in wood processing industry within the forestry-wood chain in Slovakia: A Q methodology study to identify future orientation in the sector. Forests, 8(6), 210. https://doi.org/10.3390/f8060210

Loučanová, E., Parobek, J., \& Paluš, H. (2014). Identification of Slovak customers' requirements for storage furniture based on the KANO model. Acta Facultatis Xylologiae, 56, 109-117.

Ludvig, A., Rogelja, T., Asamer-Handler, M., Weiss, G., Wilding, M., \& Zivojinovic, I. (2020). Governance of social innovation in forestry. Sustainability, 12(3), 1065.

https://doi.org/10.3390/su12031065

Marušáková, L. (2009). Best practices in Slovak forestry communication - Case study. Forestry Journal, 55(4), 401-408. https://doi.org/10.2478/v110114-009-0009-0

Ministry of Agriculture of the SR. (2018). Proposal of the national program for the utilization of wood potential in the Slovak Republic 2018. Slovakia.

Nijnik, M., Nijnik, A., Sarkki, S., Muñoz-Rojas, J., Miller, D., \& Kopiy, S. (2018). Is forest related decision-making in European treeline areas socially innovative? A Q-methodology enquiry into the perspectives of international experts. Forest Policy and Economics, 92, 210-219. https://doi.org/10.1016/j.forpol.2018.01.001

Nybakk, E., Lawrence, A., \& Weiss, G. (2015). Innovation in forest management for new forest owner types - A Literature Review. Background Paper of Working Group 2 "New forest management approaches", COST Action FP1201 "Forest Land Ownership Changes in Europe: Significance for Management and Policy". https://www.researchgate.net/publication/303823188_Innovation_in_Forest_ Management_for_New_Forest_Owner_Types_-_A_Literature_Review

Nybakk, E., Crespell, P., Hansen, E., \& Lunnan, A. (2009). Antecedents to forest owner innovativeness: An investigation of the non-timber forest products and services sector. Forest Ecology and Management, 257(2), 608-618. https://doi.org/10.1016/j.foreco.2008.09.040 
OECD. (2018). Oslo Manuals. The measurement of scientific and technological activities. European Commission.

Orazio, C., Cordero Montoya, R., Régolini, M., Borges, J., Garcia-Gonzalo, J., Barreiro, S., Botequim, B., Marques, S., Sedmák, R., Smreček, R.., Brodrechtová, Y., Brukas, V., Chirici, G., Marchetti, M., Moshammer, R., Biber, P., Corrigan, E., Eriksson, L. O., Favero, M., Galev, E., Hengeveld, G. M., Kavaliauskas, M., Mozgeris, G., Navrátil, R., Nieuwenhuis, M., Paligorov, I., Pettenella, D., Stanislovaitis, A., Tomé, M., Trubins, R., Tuček, J., Vizzarri, M., Wallin, I., Pretzsch, H., \& Sallnäs, O. (2017). Decision support tools and strategies to simulate forest landscape evolutions integrating forest owner behaviour: A review from the case studies of the European Project, INTEGRAL. Sustainability, 9(4), 599. https://doi.org/10.3390/su9040599

Paluš, H. (2015). Changes in energy wood supplies in the Slovak Republic. In Wood Processing and Furniture Manufacturing Challenges on the World Market and Wood-Based Energy Goese Global. Proceedings of Scientific Papers (pp. 261-266). WoodEMA. Zagreb.

Paluš, H., Kaputa, V., Parobek, J., Šupín, M., Halaj, D., Šulek, R., \& Fodrek, L. (2011). Trh s lesníckymi službami (Technical). Technická univerzita vo Zvolene (in Slovak).

Paluš, H., Loučanová, E., \& Kaputa, V. (2015). Kontrakty a manažment rizika inovačného procesu poskytovate’ov lesníckych služieb na Slovensku. Zprávy lesnického výzkumu, 61, 77-86.

Paluš, H., Mat'ová, H., \& Križanová, A. (2014). A survey of awareness of forest certification schemes labels on wood and paper products. Acta Facultatis Xylologiae, 56, 129-138.

Parobek, J., Paluš, H., Kalamárová, M., Loučanová, E., Šupín, M., Križanová, A., \& Štofková, K. R. (2016). Energy utilization of renewable resources in the European Union - Cluster analysis approach. BioResources, 11(1), 984-995. https://doi.org/10.15376/biores.11.1.984-995

Parobek, J., Paluš, H., Kaputa, V., \& Šupín, M. (2014). Analysis of wood flows in Slovakia. BioResources, 9(4). https://doi.org/10.15376/biores.9.4.6453-6462

Pätäri, S., Arminen, H., Albareda, L., Puumalainen, K., \& Toppinen, A. (2017). Student values and perceptions of corporate social responsibility in the forest industry on the road to a bioeconomy. Forest Policy and Economics, 85(Part 1), 201-215. https://doi.org/10.1016/j.forpol.2017.10.009

Perz, J., Ussher, J. M., \& Gilbert, E. (2013). Constructions of sex and intimacy after cancer: Q methodology study of people with cancer, their partners, and health professionals. BMC Cancer, 13, 270. https://doi.org/10.1186/1471-2407-13-270

Rametsteiner, E., \& Weiss, G. (2006). Innovation and innovation policy in forestry: Linking innovation process with systems models. Forest Policy and Economics, 8(7), 691-703. https://doi.org/10.1016/j.forpol.2005.06.009

Šálka, J. (2004). Inovačná politika v lesnom hospodárstve SR. Podpora Inovácií a Podnikania v Lesníctve (pp. 32-40). Lesnícky výskumný ústav.

Šálka, J., Longauer, R., \& Lacko, M. (2006). The effects of property transformation on forestry entrepreneurship and innovation in the context of Slovakia. Forest Policy and Economics, 8(7), 716-724. https://doi.org/10.1016/j.forpol.2005.06.017

Salloch, S., Otte, I. C., Reinacher-Schick, A., \& Vollmann, J. (2018). Physician perspectives on the impact of patient preferences and the role of next-of-kin of patients in evidence-based decision-making: A qualitative interview study from oncology. Zeitschrift Für Evidenz, Fortbildung Und Qualität Im Gesundheitswesen, 131, 46-52. https://doi.org/10.1016/j.zefq.2018.02.002

Sarvašová, Z. (2008). Inovácie v rekreačných službách spätých s lesom - prípadová štúdia. In Marketing a Obchod. Národné lesnícke centrum (in Slovak).

Sarvašová, Z., \& Kovalčík, M. (2010). Challenges for diversification of activities in private forest sector in Slovakia. In Small scale forestry in a changing world. Slovenian Forestry Institute, Ljubljana.

Sarvašová, Z., \& Šálka, J. (2012). Integrácia úžitkov verejnoprospešných funkcií lesov do trhového mechanizmu - Teórie a zahraničné skúsenosti. Vydavatelstvo TU vo Zvolene (in Slovak). 
Sarvašová, Z., \& Lásková, J. (2009). Kooperácie podporujúce inovácie v rekreačných službách spätých s lesom. In Aktuálne Otázky Ekonomiky Lesného Hospodárstva Slovenskej Republiky. Národné lesnícke centrum (in Slovak).

Sarvašová, Z., Šálka, J., Dobšinská, Z., \& Kovalčík, M. (2014). The comparison of innovations in Slovakian forestry between 2002 and 2010-a shift to multifunctionality? South-East European Forestry, 5(2), 125-134. https://doi.org/10.15177/seefor.14-11

Scarlat, N., Dallemand, J. F., Monforti-Ferrario, F., \& Nita, V. (2015). The role of biomass and bioenergy in a future bioeconomy: Policies and facts. Environmental Development, 15, 3-34. https://doi.org/10.1016/j.envdev.2015.03.006

Schmolck, P. (2017). PQMethod manual. http://schmolck.org/qmethod/

State enterprise Forests of the Slovak Republic. (2017). Annual report of forests of the Slovak Republic. https://www.lesy.sk/files/forest-2018/annual-report/lesy-sr-vs-2017-en.pdf (in Slovak).

Steelman, T. A., \& Maguire, L. A. (1999). Understanding participant perspectives: Q-methodology in national forest management. Journal of Policy Analysis and Management, 18(3), 361-388. https://doi.org/10.1002/(SICI)1520-6688(199922)18:3<361::AID-PAM3>3.0.CO;2-K

Štěrbová, M., Loučanová, E., Paluš, H., Ivan, L., \& Šálka, J. (2016). Innovation strategy in Slovak forest contractor firms - A SWOT analysis. Forests, 7(6), 12. https://doi.org/10.3390/f7060118

Štěrbová, M., \& Šálka, J. (2016). Peňažné stimuly k inováciám v sektore lesníckych služieb na Slovensku z Programu rozvoja vidieka. Zprávy Lesnického Výzkumu, 61, 151-157.

Valenta, A. L., \& Wigger, U. (1997). Q-methodology. Definition and application in health care informatics. Journal of the American Medical Informatics Association, 4(6), 501-510. https://doi.org/10.1136/jamia.1997.0040501

Wackernagel, M., Schulz, N. B., Deumling, D., Linares, A. C., Jenkins, M., Kapos, V., Monfreda, C., Loh, J., Myers, N., Norgaard, R., \& Randers, J. (2002). Tracking the ecological overshoot of the human economy. Proceedings of the National Academy of Sciences, 99, 9266-9271. https://doi.org/10.1073/pnas.142033699

Walder, P., \& Kantelhardt, J. (2018). The environmental behaviour of farmers - capturing the diversity of perspectives with a Q methodological approach. Ecological Economics, 143, 55-63. https://doi.org/10.1016/j.ecolecon.2017.06.018

Watts, S., \& Stenner, P. (2005). Doing Q methodology: Theory, method and interpretation. Qualitative Research in Psychology, 2(1), 67-91. https://doi.org/10.1191/1478088705qp022oa

Weidenfeld, A. (2018). Tourism diversification and its implications for smart specialisation. Sustainability, 10(2), 319. https://doi.org/10.3390/su10020319

Weiss, G., Pettenella, D., Ollonqvist, P., \& Slee, B. (Eds.). (2011). Innovation in forestry: Territorial and value chain relationships. CABI International. Oxfordshire. https://doi.org/10.1079/9781845936891.0000

Zaušková, A., Loučanová, E., Sarvašová, Z., \& Fodrek, L. (2009). Inovačný governance a lesníctvo. In J. Šálka \& Z. Sarvašová (Eds.), Governance v Lesníctve (pp. 156-202). Národné lesnícke centrum (in Slovak).

Zoznam.sk. (2019). Telefónny zoznam. https://telefonny.zoznam.sk/

Živojinović, I., Weiss, G., Wilding, M., Wong, J. L. G., \& Ludvig, A. (2020). Experiencing forest products - An innovation trend by rural entrepreneurs. Land Use Policy, 94, 104506. https://doi.org/10.1016/j.landusepol.2020.104506

Živojinović, I., \& Wolfslehner, B. (2015). Perceptions of urban forestry stakeholders about climate change adaptation - A Q-method application in Serbia. Urban Forestry and Urban Greening, 14(4), 1079-1087. https://doi.org/10.1016/j.ufug.2015.10.007 